\title{
CEO Compensation and Credit Default Swaps: Evidence from the U.S. and Germany
}

\author{
Hsin-Hui Chiu \\ Argyros School of Business \\ Chapman University \\ Orange, CA 92866 \\ e-mail: chiu@chapman.edu \\ Eva Wagner \\ Department of Finance \\ Johannes Kepler University Linz \\ Altenberger Str. 69, \\ 4040 Linz, Austria \\ e-mail: eva.wagner_1@jku.at
}

\begin{abstract}
Executive compensation is designed to create incentives for CEOs to act in the best interest of shareholders. Short-term (bonus) and equity-based incentives induce risk taking behaviors of the CEO that could further change a firm's risk exposure. This article examines the linkage between compensation components and the impacts on a firm's credit risk using data from the U.S. and Germany. In the U.S., we find a positive relation between equity-based compensation and credit default swap spreads. Similar positive relation is also found between short-term incentive bonus pay suggesting compensation infuce more risk taking for the U.S. firms. However, we do not find significantly positive relation between equity-based incentive and a firm's credit risk in German firms. Our results seem to indicate that bonus pay is large portion of pay for German CEOs therefore restraint CEOs' risk taking strategies.
\end{abstract}




\section{Introduction}

Agency problem has been examined extensively in finance literature and was found to affect corporate function in great deal (Holmstrom 1979). In modern business world, ownership of a firm is usually separate from management. These arrangements further induce mismatching incentives from owners and managers. Empire building and excessive perquisite consumptions are examples of executive personal interests from prior literature (Jensen and Meckling 1976, Amihud and Lev 1981) that will not maximize shareholders wealth. Several mechanisms have evolved to solve agency problem in modern corporate world, i.e. takeover threat, board of director monitoring system and executive pay package.

Executive compensation is designed to align corporate agents' (CEOs and other executives) incentives with those of its owners (shareholders). CEO pay is typically composed by fixed salary, bonus, stocks granted, options granted and long term incentive plans. Some compensation pay is more performance based (i.e. bonus) and others are used to make CEOs shareholders themselves (equity based incentives). A certain change in the compensation structure is likely to change executives' incentives and alter their behaviors, particularly in risk-taking and shifting strategies. Changing strategies leads to settings of capital structure, usage of debts and eventually increase/decrease bankruptcy risk exposures for a company.

This article examines the linkage between compensation components and the impacts on a firm's credit risk. Few studies have examined the relation between CEO ownership/compensation and bond returns or credit risk (Carlson and Lazrak 2009). However, almost all studies focus on the U.S. firms. We examine the relations of compensation and firms credit risks in two very distinct markets: U.S. and Germany. We are also particularly interested in performance based and equity based compensation and their impacts on a firm's risk exposure. 
Germany and the U.S. markets are the classic representatives of divergent financial systems. Thus, the German financial system is seen, in particular, as a classic example of a bank based and control oriented financial system. Whereas the U.S. market, on the other hand, is regarded as a traditional representative of a market oriented financial system (see Allen and Gale (1995)). A central role in the discussion of financial systems is played by the different kind of relationships between companies and banks and the resulting scope and extent of informational advantage. In countries of the bank oriented type like Germany long-term customer bank relations are the norm, while in market oriented countries like the U.S., a less intensive relation between company and bank is evident. The fundamental difference between the corporate governance systems in Germany and the U.S. is referred to as an insider versus outsider system' in the literature.

We choose these two distinct markets to examine compensation structures and the impacts on firms' risk exposure. Is compensation structure comparable worldwide or a countrywide phenomenon? How do incentive pays (bonus and equity based) alter CEOs' behavior and further leads to firms' credit risk?

The global credit derivative market has grown enormously in recent years. The Credit Derivative Report 2006 of the British Bankers’ Association (BBA) which carries out extensive international market research yearly, and whose studies also supply detailed information regarding market structure, reported that the market was worth approximately 350 billion U.S. Dollars in1998. In 2004 the outstanding nominal volume was approx. 5,021 billion U.S. Dollars, in 2006 it was approx. 20,207 billion U.S. Dollars and for the end of 2008 the prognosis by the BBA was approx. 33,120 billion U.S. Dollars. The volume has quadrupled from 2004 to 2006. Although the outstanding notional amount subsequently fell back to about $\$ 31$ trillion by June, 30, 2009, the credit derivative market is considered as belonging to the fastest growing segment of the international financial system. Within the market for credit derivatives the Credit Default Swaps (CDS) are the most extensively used 
and the most important instrument. The market share of CDS most recently amounted to around one third - according to estimations by the BBA the share of CDS on the entire market will settle at around $30 \%$ in 2008 as well.

Due to the fact that there are particularly informed participants trading on the CDS market - first and foremost banks - credit risk relevant information can basically appear on the CDS market first. CDS spreads can reflect private information before the information is made public i.e. before these are reflected in the stock prices (see Acharya and Johnson (2005) for evidence on insider trading in CDS markets). Blanco, Brennan and Marsh (2005) claim with regard to price finding on markets: "Price discovery will occur in the market in which informed traders transact most." It is beyond the scope of this study to compare and conclude price discovery of these two markets ${ }^{1}$.

We estimate short term incentive pay (bonus) and equity based pay (stocks and options granted) impact on firms' credit risk. We adopt different econometric models to examine this relationship. In the U.S. data, we find a positive relation between equity based compensation and CDS spread of the firm. The higher the equity based component, the more credit risk a firm is exposed to. We also find a similar positive relation between short-term incentive bonus pay and CDS spread. Short term compensation incentive also increases a firm's credit risk.

On the other hand, German compensation speaks a different language. Equity based compensation is not a significant driver of a firm's credit risk. There exists a negative relation between bonus pay and CDS spread. Bonus is a relative larger component of CEO pay in Germany compared to that in the U.S (See descriptive table). A large component of German CEO pay is tied to short term incentive. Although there could be limited downside risk for CEOs to choose risky project, the high proportion of the pay from bonus could restraint

\footnotetext{
${ }^{1}$ Available empirical investigations regarding price leadership have examined the lead-lag relations between the three markets: bonds, stocks and CDS market and not explicitly based on the CDS and stock market (see Forte and Pena (2005), Longstaff, Mithal, and Neis (2005) and Norden and Weber (2004). The study allows one to conclude that the stock markets as well as the CDS market are, regarding information, ahead of the bond market. In two out of three relevant studies mentioned the stock market is, as opposed to the CDS market, price leader. The study by Longstaff, Mithal, Neis (2005) shows no exact price leadership in either of the two markets.
} 
CEOs' risk taking behaviors. This could possibly explain our findings on negative relation between bonus and credit risk; we offer other explanations in our discussion of the results.

Our article contributes to this literature by showing that managerial compensation is a significant determinant of a firm's credit risk in the U.S. However, managerial compensation could speak a different language in Germany and influence a firm's credit risk differently. We organize the paper as the following. In section 2 we discuss the evolvement of CDS market. We also review prior literature and develop several hypotheses in this section. In section 3 we describe our data. We present empirical analysis in section 4 and conclude in section 5 .

\section{CDS Market, Literature and Hypotheses Development}

\subsection{Development of the Credit Derivatives Market}

In the mid-nineties new derivative financial instruments for the transfer of credit and credit risks were developed. As with credit sales, credit derivatives have gained in importance internationally in recent years. Credit derivatives are derivative financial contracts where the payoff and performance value are dependent on the credit risks of a reference entity (underlying). A risky credit risk position (i.e. a bond or a loan), whose credit risk should be transferred is generally meant when referring to underlying. Credit derivatives enable the separation of credit risks from the original business and separate trade i.e. the transfer of the

risk components to the capital market. An important area of application for credit derivatives is the management of default risks of bank loan portfolios. The basically illiquid credit risks (up to now) in the traditional credit business have been made tradeable by credit derivatives. With credit derivatives only the credit risk, not the credit (the reference entity) itself, is transferred - therefore a minor liquidity amount is necessary. Most credit derivatives are unfunded i.e. they do not require an up-front capital investment. It is therefore, with regard to arising transaction costs, efficient. 
With a CDS the protection seller or investor takes over the fixed default risk, defined by credit events, of a reference debtor for a set period. In return for taking the credit risk the protection seller receives a regular premium from the protection buyer. This premium, a socalled CDS spread, is expressed in basis points of the nominal per annum ${ }^{2}$. For instance, this means that for a premium of 200 basis points (bp) with a contract volume of $€ 5$ million, a premium payment of $€ 100,000$ per year is to be made. In the case of the occurrence of a credit event (for example bankruptcy or failure to pay), and physical settlement, the protection seller pays the protection buyer a nominal amount of the contract (eg. $€ 5$ mil) and receives in return the defaulted bond. The protection seller is then in possession of a claim against the reference debtor. Alternatively, cash settlement, rather than physical settlement, may be specified in the contract. The cash settlement amount is equal to the difference between the par value of the bond or loan and its market value after default. Should no credit event occur over the life of the contract, then the contract expires at the maturity date. More than $90 \%$ of the market participants, according to research, depend on the standard documentation of the International Swaps and Derivatives Association (ISDA) when drawing up a contract. The functional method of a Credit Default Swap is depicted in Figure 1.

Economically a strong resemblance between Credit Default Swaps and credit insurance is apparent. What differentiates it from default insurance - and enables it to be a specific instrument - is that CDS is traded daily and the spreads reflect the default risk, including the (unsure) recovery rate, of a credit position almost immediately. The CDS market is an OTC market (over-the-counter-market). The players are professional market participants, whereby banks, hedge funds and insurance companies dominate the international market. In the meantime the CDS is, for the well-known companies on the capital market, very liquid.

CDS and bond market are related markets: the prices i.e. spreads of both are influenced by the credit risk of a company; so that information about the credit risk of the company will also

\footnotetext{
${ }^{2}$ The Spread is quoted annually but usually paid quarterly.
} 
be reflected in the prices. Based on the structural differences of the markets, this information can be reflected in the prices with different time delays.

The relation between CDS spreads and bond spreads is the central focus of some empirical studies. The theoretically postulated close connection between the two credit risk premiums is also empirical. The studies of Hull, Predescu and White (2004), Longstaff, Mithal and Neis (2005) Houweling and Vorst (2003) as well as Blanco, Brennan and Marsh (2005) basically establish a close connection between CDS spreads and bond spreads.

Recent research shows that corporate bond spreads are increasingly influenced by other factors (not credit risk relevant) e.g. by tax aspects and liquidity risks. Different studies show that the expected default loss components only accounts for a small percentage of the credit risk premium of bonds (Amato and Remolona 2003). The CDS market, on the other hand, is the market where credit risks can be traded easiest. CDS offer the possibility of buying or selling credit risks without having to sell or buy the underlying bond.

Longstaff, Mithal and Neis (2005) show that a substantial percentage of the credit spread of bonds are determined by liquidity factors. Zhu (2004) discovered in a study that liquidity plays a major role in the explanation of price differences on the bond- and CDS market. CDS are, meanwhile -because of the comparably high liquidity - the preferred instruments of the arbitrage dealers to implement their strategies.

An important point with the evaluation of credit spreads with bonds is identifying the correct risk free interest rates. The suitable riskless interest rates are, according to recent research, no longer government yield bonds but rather swap rates. While with corporate bond spreads above the benchmark risk free interest rate estimates have to be made, in the case of CDS spreads the 'true' credit spread is already reflected. The CDS market is the market which reflects the credit risks of a reference entity most reliably, whereas in the bond market irregularities appear. 
The CDS market is also the market where credit risks can be traded simply and without restrictions. In empirical papers the question which of the two markets is price leader has already been discussed. The presently available empirical evidence (Blanco, Brennan and Marsh 2005, Deutsche Bundesbank (2004), Norden and Weber (2004) as well as Zhu (2004) implies that the CDS market displays price leadership when compared with the bond market and that it is more efficient in pricing. Accordingly, the CDS market is, meanwhile, the leading credit risk market and shows the development of the credit quality of debtors early on.

\subsection{Related Research and Hypotheses Development}

In Merton's 1976 seminal paper, the value of a corporate debt depends on three items: the required return on riskless debt, the provisions contained in the indenture, and the probability that the firm will be unable to satisfy some or all indenture requirements. Credit risk is particularly related to the probability of default that is a function of the volatility of a firm's operations.

It has long been described in Holmstrom (1979) that principal-agent relations are prevalent in economic organizations. A problem of moral hazard may arise when an individual agent engage in risk sharing under conditions those actions taken privately will affect the outcome. The source of this moral hazard problem is due to asymmetric information among individuals and actions taken by these individuals cannot be observed and contracted upon. Through the mechanism of executive compensation, firms may be able to decrease the level of agency problem and align manager personal interests with shareholders wealth ${ }^{3}$.

Several studies have examined compensation structure and its impacts on managerial firm risk management. Tufano (1996), Smith and Stulz (1985), and Stulz (1984) discuss managerial risk aversion as a driver of corporate risk management. Managers whose human capital and wealth are poorly diversified strongly prefer to reduce the risk to which they are

\footnotetext{
${ }^{3}$ See Jensen and Meckling (1976), and Amihud and Lev (1981) for discussion on CEO shirking and excessive perquisites consumption. Shleifer and Vishny (1989) discuss on CEO entrenchment problem.
} 
exposed. Model of Smith and Stulz suggests that managers with greater stock ownership prefer more risk management, while those with greater option holdings prefer less risk management. Stocks provide linear payoffs whereas options provide convex payoffs.

Tufano (1996) examines the corporate risk management activities in gold mining industry. This study confirms the finance theory predicted by Smith and Stulz (1985) that firms manage less gold price risk when managers hold more stock options. Firms whose managers have more wealth invested in the firm's stock manage more gold price risk.

Compensation could include performance sensitive or/and performance insensitive components. Murphy (1999) has documented the rapid growth of equity-based compensation (in the form of stock and options) in recent years. Fernandes et al (2009) also find that U.S. executives receive more equity-based compensation compared to executives in other countries. The average CEO in U.S. receives $42 \%$ of his pay in the form of stock or options, more than double compared to CEOs in other countries.

The sensitivity of CEO wealth to stock price, or delta, is seen as aligning managers' incentives with shareholders incentives (Coles, Daniel and Naveen 2006). High delta will lead to hard working CEOs and more aligned shareholders interest with respect to risk taking behavior. However, high delta could also decrease risk taking if the CEO is extremely undiversified in personal portfolios. Options-based compensation could potentially reduce risk aversion to risky yet positive NPV projects given the convex payoffs.

However, based on special features of the package it also provides managers different incentives for risk taking. This may leads to a change in companies 'risk profile. We survey in the following of lieterature on agency problem and excutive compensation to develop testable hypothese.

Equity-based executive compensation may mitigate these conflicts of interest by providing a more direct link between manager and shareholder wealth. However, contracting 
theory predicts that greater equity-related compensation may exacerbate the agency problems of debt (Bryan etal 2006).

Benston and Evan (2006) studies banks CEO ownership structure and suggests that CEOs who are not significant stockholders generally will avoid taking actions that shift risk to debtholders. Unlike limited-liability stockholders (who can lose only the funds invested in their shares), the expected value of high-risk projects for these CEOs generally is negative. Several forms of incentive based compensation could be used to align the interests of CEOs with that of shareholders (to give incentives for risk taking or risk shifting). They postulate that short-term incentives (bonuses) may be more effective than long-term incentives (stock options and rights and non-stock-related long-term incentive pay) as an incentive for CEOs to shift risk to debt holders. Bonuses are linked with accounting measures. They can be "manipulated" and so there is no (or no early) negative consequence. CEO gets bonus, even when the firms fails later (see also Noe et et al. 1996). Stock options offer the possibility of greater rewards should the risks taken succeed.

In a study that examines the role of corporate governance in the 2007-2008 credit crisis, Erkens, Hung and Matos (2009) hypothesize that CEO bonus pay is associated with larger losses during the crisis and more risk taking before the crisis. Equity-based compensation is associated with smaller losses and less risk taking. They define equity-based compensation as the sum of restricted shares, long-term incentive plans (LTIP), and stock option awards scaled by the sum of salary and other annual compensation. Bonus pay is scaled by the sum of salary and other annual compensation.

From the Merton model, it can be derived that investing in risky projects increases the value of the option the shareholders have on a levered firm. This is the asset substitution or risk shifting problem (see also Galai and Masulis (1976) and Jensen and Meckling (1976). Jensen and Meckling (1976) suggest that when risky debt is outstanding, equity has a convex payoff structure such that shareholders gain by shifting into higher risk projects even when 
the incremental net present value is negative. Their analysis suggests, that the proportion of equity controlled (owned) should influence the firm's policies and also leverage and CDSspreads.

However, Bagnani et al suggest that management's stake becomes large, management's and shareholders' interests may become less well aligned for two reasons. First, as management's stake increases, its wealth becomes less well diversified, so management becomes concerned about the undiversifiable risk of its stake. Second, ownership of equity also implies control of votes; as management's stake increases, it can use its control of votes to protect its position. As a result of these conflicting forces, both theoretical models and empirical evidence indicate that greater managerial ownership tends to affect shareholder wealth positively at low levels of ownership and may affect shareholder wealth negatively at higher levels of ownership. In this paper, they find support for the hypothesis that the relation between bondholder returns and managerial ownership is not monotonic; there is no relation between bond returns and ownership for ownership below 5 percent, a positive relation for ownership between 5 and 25 percent, and a weak negative relation for ownership in excess of 25 percent. Past arguments state that managers prefer less risky investments and lower leverage, so they can reduce the uncertainty of their undiversifiable "human capital" investment in the firm (Amihud and Lev (1981)) and lessen the probability of bankruptcy (Jensen and Meckling (1976)). The managers' interests, therefore, are closer to the interests of bondholders who, like managers, are exposed to the downside risk of negative investment return outcomes and do not share significantly in upside return outcomes. In the absence of any incentive mechanisms, managers would pursue, their own interests by taking low risk projects at the expense of the stockholders and to the general benefit of bondholders. First, Agrawal and Mandelker (1987) and Saunders, Strock, and Travlos (1990) note that managers' increased nonhuman wealth investment in the firm may become so large as to make them increasingly sensitive to the potentially undiversifiable, nonsystematic risk of the firm. If their 
human wealth is also relatively job specific, this will reinforce managerial risk aversion at high managerial stake-holding levels. Therefore, the second hypothesis examined in this study is that the relation between corporate bond returns and managerial stockholdings is nonmonotonic. Specifically, at large managerial stockholding levels, the positive relation between bond returns and managerial stockholdings may become weaker or, beyond a certain level, even switch. Based on the literature above, we hypothesise the following:

Hypothesis 1: There is a positive relation between equity-based compensation and CDS spreads.

Hypothesis 2: There is a positive relation between short term incentive pay (bonus) and CDS spreads.

Hypothesis 3: There is a positive relation between CEO ownership and CDS spreads.

\section{Sample Selection and Data Description}

\subsection{Sample Selection}

The primary focus of our study is to examine the impact of CEO compensation of the firm on firm's default risk measured by credit default spreads (CDS). CDS market has become very liquid since 2004 (other researcher report a relatively high liquidity since 2003, see for example Tang and Yan (2006). Therefore, we have selected sample period for our study to be between 2004 and 2008 to achieve maximum and sensible data observations. In addition, we restrict our attention to five-year maturity contracts as well as senior unsecured debt whose liquidity is highest. Our samples include all US and German companies which are liquid since the beginning of 2004 on. Daily CDS spreads are obtained from Thomson Reuters Datastream (CMA data) for both our U.S. and German sample. Using this data, we calculate a CDS spread for each firm-year by averaging the daily observations.

For our U.S. sample of firms, we acquire CEO compensation and firm characteristics information based on COMPUSTAT Eecutive Compensation database. Daily stock returns and stock price volatility (standard deviation) is acquired from the Center for Research in 
Security Prices (CRSP). For our German sample of firms, we hand collect information on compensation structure from the annual reports of the companies. Thomson Reuters Datastream as well as Worldscope Thomson Reuters is the source of firm characteristics information. Credit ratings of S\&P and Moodys for all companies are obtained from Bloomberg.

\subsection{Variable Definition and Data Description}

\subsubsection{Executive compensation}

Our compensation variables for the U.S. are obtained from ExecComp database. SALARY refers to the dollar value (in thousands) of base salary earned by the CEO during the fiscal year. BONUS refers to the dollar value (in thousands) of bonus earned by the CEO during the fiscal year. TDC1 is the total compensation as calculated under the 1992 reporting format and includes SALARY, BONUS, Other Annual, Total Value of Restricted Stock Granted, Total Value of Stock Options Granted, Long-Term Incentive Payouts, and All Other Total (in thousand \$). Other Annual refers to the dollar value of other annual compensation not properly categorized as salary and bonus. Restricted Stock Grants refers to the dollar value of restricted stock granted determined as the date of the grant. Long-Term Incentive Payout is the amount paid out to the CEO under the company's long-term incentive plan. These plans measure the company performance over a period of more than one year (generally three years). Equity compensation is defined as the sum of options, long-term incentive plan (LTIP), and restricted shares (in thousand \$).

Our compensation variables for the German sample are obtained from the annual reports of the companies. Since many German companies (even not the ones listed in the DAX 30 Deutscher Aktienindex 30) didn't follow the recommendation "Individualized disclosure of Management and Supervisory Board compensation” of the German Corporate Governance Code we were restricted to 22 companies. From the financial year 2006 on German listed 
companies have to report the Management compensation individualized (the corresponding law, the "Vorstandsvergütungsoffenlegungsgesetz (VorstOG)" is in force sind August 2005). BONUS refers to the euro value (in thousands) of bonus earned by the CEO during the fiscal year. TDC 1 is the total compensation and comprises the same components as above mentioned (in thousand $€$ ). Equity compensation is also the sum of options, long-term incentive plan (LTIP), and restricted shares (denominated in thousand $€$ ).

\subsubsection{CDS spreads}

CDS spreads for both samples are from Thomson Reuters Datastream (CMA data). Annual CDS spreads (in basis points) are the average of daily CDS spreads within each calendar year (1. January 2004 - 31. December 2008, 5 years).

\subsubsection{Credit Ratings}

Following Reeb et al. (2001) and Anderson et al. (2003), bond ratings are computed using a conversion process in which AAA+ rated bonds are assigned a value of 23 and D rated bonds are assigned a value of 1 within the S\&P ratings. Similarly, Aaa + bonds receive a value of 23 and D rated bonds receive a value of 1 within the Moody's ratings. For German companies we use Rating which refers to Moody's rating in general but is sometimes completed with S\&P rating information in order to keep the sample (the assumption here is that the two credit risk indicators are comparable). Prior research has shown that credit ratings are important when pricing credit risk overall (see for example Aunon-Nerin et al. 2002, Tang and Yan 2006). They are a kind of "fundamental control variable" beyond other factors. We expect to see an inverse relationship, as the lowest default risk measured by rating agencies (highest value 23 in our investigation) should be associated with lower CDS spreads.

\subsubsection{Firm specific variables}

\section{Structural variables}


We have several firm specific respectively control variables in place. Merton's approach (1974) provides a unique insight into the theoretical relationship between equity value, volatility, default probability and credit spreads. From the so called structural models can be derived that CDS spreads are determined by equity market data such as volatility and market leverage. Recent research shows, that these "structural variables" have significant impact on the levels of CDS premiums (see for example Aunon-Nerin et al. 2002 and Ericsson et al. 2004). From this theory we expect to see a higher CDS spread with higher leverage (proxied with Long term debt to Total Assets) and with higher volatility (our proxy for volatility of a firm's asset is equity standard deviation). In Merton's model the volatility of a firm's assets provides important information about the firms's probability of default. Campbell and Taksler (2003) show that firm level volatility (as well as credit ratings) can explain a large portion of the variation in corporate bond yields. We expect to see that higher volatility (standard deviation) is associated with higher credit risk, e.g. higher CDS spreads.

\section{Size}

As a measure of firm size we include the value of total assets. The findings in Carlson and Lazrak (2009) and Das et al. (2007) suggest that there is a negative relationship between firm size and CDS spread meaning that less default risk is inherent in larger firms. One can argue that bigger firms are better diversified than smaller ones and have therefore a less probability of default. The reputation of big companies in the credit/bond markets is higher and they are confronted with less agency costs. (This argument gives also rise to the contrary hypothesis: if larger firms present less default risk this should lead to a higher lending willingness and to a higher leverage ratio; this in turn should be associated with a higher credit risk, e.g. higher CDS spreads, see also Rajan and Zingales (1995) for further arguments).

\section{Profitability}

Profitability is gauged by Return on Assets (ROA), calculated as net income divided by total assets. More profitable firms bear less default risk (better!). The predicted sign between 
CDS Spreads and ROA is therefore negative (Das et al. (2007) found a strong negative relationship between ROA and CDS spreads).

As a second market based measure of profitability we employ RETURN, calculated as daily stock return over the calendar year. Higher stock returns should be associated with a lower probability of default and therefore lower CDS spreads (Byström 2005 finds that CDS spreads are significantly negatively correlated to contemporaneous stock returns at the index level).

\subsubsection{Summary statistics}

Table 1 presents summary descriptive statistics by country over time. It shows that during the financial crisis of 2008 the CDS spreads rose on average dramatically. Table 2 presents summary statistics by country. Our sample consists of 110 yearly CDS spreads from 2004 to 2008 from 22 German firms and of 1559 yearly CDS spreads (observations) from 418 US companies. Our sample of 418 US firms and 22 German firms is required to have CEO compensation data and firm specific information. CDS spreads for both samples are from Thomson Reuters Datastream (CMA data). Annual CDS spreads (in basis points) are the average of daily CDS spreads within each calendar year (1. January 2004 - 31. December 2008, 5 years). Leverage ratio is Long term debt to Total Assets (obtained from Compustat for US firms and from Worldscope Thomson Reuters for German firms). Return is daily CRSP returns during the calendar year (CRSP returns for the US sample and for the German companies calculated from Thomson Reuters Datastream). Equity standard deviation (std dev) is calculated each year at the firm level from daily CRSP returns (or calculated from Thomson Reuters Datastream) during the calendar year. Return on Assets (ROA) is net income divided by total assets. The variable bonus/total compensation is bonus divided by total compensation (sum of salary, bonus, other annual, total value of restricted stock granted, total value of stock options granted, long term incenctive payouts (LTIP), and al other compensation). 
Equity/total compensation is the ratio of the sum of options, LTIP, and restricted shares) to total compensation.

The average CDS spread is lower in the German sample as well as leverage ratio. There is no remarkable difference in average stock returns as well as standard deviation. Average rating is slightly higher for German companies. German firms are on average bigger than U.S. firms in our samples. Profitability measured by return on assets (ROA) is on average higher in U.S. firms. In terms of CEO compensation, Table 2 shows that CEO compensation in Germany is much more tilted towards bonus compensation than in the U.S. The bonus component is on average $50 \%$ of total compensation, in the U.S. only $13 \%$. This is a distinct difference in compensation structure. The second component of interest, equity compensation does not differ substantially between the two countries.

\section{Empirical Analysis}

\subsection{Econometric Model}

Panel data for 418 US firms and 22 German forms for the period 2004 to 2008 were used to explain some of the determinants of CDS spreads and to examine whether CEO compensation structure is related to credit risk. The empirical assessment is based on the basic model given by Equation (1).

$$
\begin{aligned}
& \ln \left(\text { spread }_{i \text { it }}=\alpha+\beta_{1} \text { rating }_{i, t}+\beta_{2} \text { rratio }_{i, t}+\beta_{3} \text { return }_{i, t}+\beta_{4} \text { stddev }_{i, t}+\beta_{5} \text { ROA }_{i, t}\right. \\
& +\beta_{6} \text { ltotalassets }_{i, t}+\beta_{7} \text { compensation variable }_{i, t}+\text { eit }
\end{aligned}
$$

where subscript $\mathrm{i}$ refers to firms, $\mathrm{t}$ refers to years from 2004 to $2008, \alpha$ is the intercept, and cit is an error term. As described in the data section, six firm specific respectively fundamental variables are applied: credit rating, leverage ratio, stock return, equity standard deviation at the firm level, return on assets and total assets. The compensation variables are 
the key variables of this study, i.e. (1) the proportion of bonus in total compensation as well as (2) the ratio of equity based compensation to total compensation.

We used several estimation methods. First, we applied pooled ordinary least squares (OLS). Table 3, columns i-ii, presents the results for the US sample and table 4, columns i-ii, for the German sample for our compensation variables of interest, the bonus and equity component of total compensation. The columns iii and iv in both panels include a year dummy for crisis 2008 (as the CDS spreads rose dramatically in comparison to all other years) and industry dummies. However, modeling the relation in this manner fails to control for unobserved firm heterogeneity, or omitted variable bias. It is therefore possible that these results are biased due to multiple occurrences of the omitted variable across time periods. In the presence of unobserved firm effects, firm fixed effects regression is commonly suggested. We test the validity of the random effects estimator by a Hausman specification test. The test rejects the random effects estimator for both samples and thus the fixed effects models are preferred. The fixed effects regressions explain the variation across time while controlling for firm-specific effects. For example, if the default risk of a particular firm is driven by a bad management, the firm-specific intercept in the fixed effect regression would capture the additional required spread component. The estimates of the fixed effects models are reproduced in columns v and vi in table 3 (US sample) and 4 (German sample).

\subsection{Empirical Results}

\section{U.S. Sample}

Our main variables of interest are the compensation components and their influence on credit risk. We hypothesized (Hypothesis 1) that there is a positive relation between equitybased compensation and CDS spreads. It is shown that the proportion of CEO's equity-based compensation clearly matters for credit risk. The coefficients in the regressions are strongly 
significant with the expected sign. A high level of the equity-based component in compensation drives credit risk and therefore CDS spreads. When CEOs' compensation is aligned with shareholders, they tend to take risky projects due to limited downside risk. This action would lead to an increase in a firm's risk exposure in terms of credit risk. The results clearly argue in favor of hypothesis 1.

Hypothesis 2 established our prediction that there is a positive relation between short term incentive pay (bonus) and CDS spreads. This hypothesis consistently received strong support, both in terms of the sign as well as statistical significance, in all three regressions. It seems that creditors perceive bonuses as incentive to CEOs to invest in risky projects. Debtholders seem to anticipate and price that risk shifting problem and therefore it is reflected in CDS spreads (for a theoretical analysis see Noe et al. (1996)).

We begin with more detailed discussions of the results of the US sample in Table 3, which provide a number of valuable insights. As discussed earlier, prior research shows that credit ratings can explain a large portion of the levels of CDS spreads or bond spreads. Credit ratings produced by the major credit rating agencies aim to measure the creditworthiness of companies, i.e. their ability to meet their debt servicing obligations. They measure credit risk and should catch firm specific credit relevant information. We predicted an inverse relationship (due to our conversion procedure) between the variables CDS spread and rating. In all models, our rating variable has a negative sign and the coefficients are statistically highly significant. This shows that ratings influence CDS spreads significantly.

Merton's (1974) model (and other structural models) can be used to explain risky debt yields. In that models credit spreads depend on leverage and asset volatility. We predicted that our proxies leverage ratio and equity standard deviation are both positively correlated with CDS spreads. As the results in all regressions show these two "structural variables" are indeed a significant determinant of CDS spreads. 
Furthermore we find that stock returns are negatively related to CDS spreads. Higher stock returns imply better future prospects and should be associated with lower default risk. This inverse relationship is shown in all regressions and is statistically highly significant. Prior research has shown that accounting based measures of profitability and CDS spreads are negatively correlated. More profitable firms bear less credit risk. We expected therefore a negative relationship between ROA and CDS spread. This hypothesis was strongly supported and the coefficients for ROA are positive and statistically significant in all models.

Furthermore we expected to see a negative association between size and credit risk spread. All in all the results do not support this hypothesis (the fixed effects models show a positive relationship). We also employed sales as a further proxy for size with similar results.

\section{German Sample}

We now turn to the results of the German sample. The variable rating shows the expected negative sign but looses significance in the fixed effects models. It can be argued that the information content of Credit ratings of German companies is less and rating agencies measure credit risk better for US located companies. One reason could be that they don't take into account sufficiently the special characteristics in European accounting, disclosure and management practices (see also Engelen (2004)). This could explain why ratings could be not such an important determinant of CDS spreads in the "German market".

Leverage ratio is a significant positive determinant of CDS spreads in the fixed effects models only. Stock return shows predominantly a significant negative relationship with our dependent variable. Equity standard deviation shows no significance in the FE models. Our further firm specific variables ROA and size (measured by total assets) display the expected sign but are not significant.

The hypothesis 1 that higher equity based compensation is associated with higher default risk because of the risk shifting problem is not supported by the results. We had hypothesized 
(Hypothesis 2) that a higher bonus component in CEO compensation is related with higher

CDS spreads. It is interesting to see that the sign is negative in all regressions and significant in the FE model. There seems to be a tendency that creditors approve bonuses. There are several possible explanations for such a tendency. One potential explanation is that bonus pay for German CEOs consist of a large portion of their total compensation ( $50 \%$ on average) compared to U.S. CEOs ( $13 \%$ on average). This high concentration of pay in bonus could restraint CEOs risk taking behavior and leads to a lower credit risk of a firm.

An alternative explanation is that markets are not that efficient in Germany and therefore creditors are not aware of a potential risk shifting problem inherent in short term incentive pay. It could also be that they value bonus payments positive as it reflects (correctly) the profitability of the firm. In the context of the financial system in Germany this could be for reasons of superior or private information. Germany is marked by a high degree of intermediation (linked to monitoring by banks). German universal banks, which are major players in the CDS market have, regarding the traded German companies on the CDS market a potential information advantage. The reason for this can be found in the special role of banks in the German financial system ("relationship banking" or "Hausbankenprinzip"). Potential channels for the generation of information are: direct equity stakes in companies, Supervisory Board members and credit relationships as well as the investment banking relationship.

It is important to note that we were restricted to a small sample for our German panel (due to the lack of compensation data) and that the results have to be interpreted with caution. But they are first evidence that some of the fundamental and well known determinants of CDS spreads are less important for German companies and that compensation structure as well as the influence on CDS spreads is different. 


\section{Conclusion}

This article examines the linkage between compensation structure and its impacts on firms' credit risk exposure. We provide evidence that some components of the U.S. CEO compensation drive the firm's credit default swap spreads. However, our German data does not find consistent results. This could be due to different portions of the CEO pays that are short-term vs. equity based. We believe this paper is the first international study that examines the relation between compensation and firms' credit risk. We are also planning to examine the relation between CEO ownership and CDS spreads in future steps. 


\section{References}

Acharya, V.V., and Johnson, T.C., 2005, Insider Trading in Credit Derivatives, Working Paper, London Business School

Allen, F., and Gale, D., 1995, A welfare comparison of intermediaries and financial markets in Germany and the US, European Economic Review 39, 179-209

Agarwal, Anup, and Gershon Mandelker, 1987, Managerial Incentives and Corporate Investment and Financing Decisions, Journal of Finance 42, 823-837

Amato, J.D., and E.M Remolona, 2003, The credit spread puzzle, BIS Quarterly Review, 5163

Amihud, Yakov, and Baruch Lev, 1981, Risk Reduction as a Managerial Motive for Conglomerate Mergers, The Bell Journal of Economics 12, 605-617

Anderson, Ronald, Sattar Mansi, and David Reeb, 2003, Founding Family Ownership and the Agency Cost of Debt, Journal of Financial Economics 68, 263-285

Aunon-Nerin, D. et al., 2002, Exploring for the determinants of credit risk in credit default swap transaction data:Is fixed income markets' information sufficient to evaluate credit risk, Working paper, HEC-University of Lausanne and FAME.

Benkert, C., 2004, Explaining Credit Default Swap Premia, Journal of Futures Markets, 76

Benston, George, and Jocely Evan, 2006, Performance Compensation Contracts and CEO's Incentive to Shift Risk to Debtholders: An empirical Analysis, Journal of Economics and Finance 30, 70-92

Blanco, R., Brennan, and S. Marsh, 2005, An Empirical Analysis of the Dynamic Relation between Investment-Grade Bonds and Credit Default Swaps, Journal of Finance 60, 2255-2281

British Bankers' Association, 2006, BBA Credit Derivatives Report, London.

Bryan, Stephen, Robert Nash, and Ajay Patel, 2006, Can the agency costs of debt and equity explain the changes in executive compensation during the 1990s?, Journal of Corporate Finance 12, 516-535

Byström, H., 2005, Credit Default Swaps and Equity Prices: The iTraxx CDS Index Market, Working Paper, Lund University.

Campbell, J.Y. and Taksler, G.B., 2003, EquityVolatility and Corporate Bonds Yields, Journal of Finance, 863-882.

Carlson, Murray, and Ali Lazrak, 2009, Leverage Choice and Credit Spread Dynamics when Managers Risk Shift, Journal of Finance Forthcoming

Das, Sanjiv R., Hanouna, Paul and Sarin, Atulya, 2007, Accounting-Based versus MarketBased Cross-Sectional Models of CDS Spreads, Working Paper.

Duffie, D., 1999, Credit Swap Valuation, Financial Analysts Journal, 73-87

Ericsson, J., Reneby, J. and Wang, H., 2004, Can Structural Models Price Default Risk? Evidence from Bond and Credit Derivative Markets, Working Paper McGill University/Stockholm Schools of Economics.

Erkens, David, Mingyi Hung and Pedro Matos, 2009, Corporate Governance in the 20072008 Financial Crisis: Evidence from Financial Institutions Worldwide, Working Paper

Forte, S., and Pena, J.I., The Market Price of Credit Risk in Stock, Bonds and CDSs: Theory and Evidence, Working Paper, ESADE Business School/Universidad Carlos III de Madrid, June 2005.

Galai, D. and R. Masulis, 1976, The Option Pricing Model and the Risk Factor of Stock, Journal of Financial Economics 3, 53-81

Holmstrom, Bengt, 1979, Moral Hazard and Observability, Bell Journal of Economics 10, 7491

Houweling, Patrick, and TonVorst, 2003, Pricing default swaps: Empirical evidence, Journal of International Money and Finance 24, 1200-1225 
Hull, John, Mirela Predescu, and Alan White, 2004, The Relationship Between Credit Default Swap Spreads, Bond Yields, and Credit Rating Announcements, Journal of Banking \& Finance 28, 2789-2811.

Jensen, Michael and William Meckling, 1976, Theory of the Firm: Managerial Behavior, Agency Costs, and Ownership Structure, Journal of Financial Economics 3, 305-60.

Longstaff, Francisa, Sanjay Mithal, and Eric Neis, 2005, Corporate Yield Spreads: Default Risk or Liquidity? New Evidence from the Credit Default Swap Market, Journal of Finance 60, 2213 - 2253

Noe, T., M. and Rebello and L. Wall. 1996, Managerial Rents and Optimal Regulatory Intervention in Troubled Banks, Journal of Banking and Finance 5, 637-660.

Norden, Lars, and Martin Weber, 2004, Informational efficiency of credit default swap and stock markets: The impact of credit rating announcements, Journal of Banking and Finance 28, 2813-2843

Rajan, R., and L. Zingales, 1995, What Do We Know about Capital Structure? Some Evidence from International Data, Journal of Finance 50, 1421-1460.

Reeb, D., Mansi, S., Allee, J., 2001. Firm internationalization and the cost of debt financing: evidence from non-provisional publicly traded debt, Journal of Financial and Quantitative Analysis 36, 395-414

Saunders, Anthony, Elizabeth Strock, and Nickolaos Travlos, 1990, Ownership Structure, Deregulation, and Bank Risk Taking, Journal of Finance 45, 643-654

Murphy, K. , A. Shleifer, and R. Vishny, 1989, Income Distribution, Market Size and Industrialization, Quarterly Journal of Economics

Smith, C., and R. Stulz, 1985, The Determinants of Firm's Hedging Policies, Journal of Financial and Quantitative Analysis 20, 391-406

Stulz, R., 1984, Optimal Hedging Policies, Journal of Financial and Quantitative Analysis 19, 1984, v19(2), 127-140.

Tang, D.Y., and Yan, H., 2006, Liquidity, Liquidity Spillover, and Credit Default Swap Spreads, Working Paper, Kennesaw State University/University of Texas at Austing SEC.

Tuffano, Peter, 1996, Who Manages Risk? An Empirical Examination of Risk Management

Practices in the Gold Mining Industry, The Journal of Finance 51, 1097-1137

Zhu, H., 2004, An empirical comparison of credit spreads between the bond market and the credit default swap markets, BIS Working Papers, No 160. 


\begin{tabular}{|c|c|c|c|c|c|c|c|c|c|c|c|c|c|}
\hline \multicolumn{14}{|c|}{$\begin{array}{l}\text { Table } 1 \\
\text { Summary Statistics CDS spreads by country over time } \\
\text { Annual CDS spreads (in basis points) are the average of daily CDS spreads within each calendar year (1. January } 2004-31 \text {. December } \\
\text { 2008) }\end{array}$} \\
\hline GERMANY & year & Obs & Mean & $\begin{array}{l}\text { Std. } \\
\text { Dev. }\end{array}$ & Min & $\operatorname{Max}$ & U.S. & year & Obs & Mean & $\begin{array}{l}\text { Std. } \\
\text { Dev. }\end{array}$ & Min & Max \\
\hline \multirow[t]{5}{*}{$\begin{array}{l}\text { cds spread } \\
\text { (bp) }\end{array}$} & 2004 & 22 & 52.36 & 50.45 & 13.27 & 245.90 & \multirow[t]{5}{*}{$\begin{array}{l}\text { cds spread } \\
\text { (bp) }\end{array}$} & 2004 & 289 & 83.36 & 112.40 & 8.14 & 998.48 \\
\hline & 2005 & 22 & 45.25 & 41.99 & 16.33 & 166.22 & & 2005 & 324 & 84.65 & 138.79 & 3.78 & 1851.28 \\
\hline & 2006 & 22 & 40.91 & 46.61 & 11.93 & 215.59 & & 2006 & 344 & 77.76 & 108.98 & 3.76 & 769.35 \\
\hline & 2007 & 22 & 45.90 & 63.81 & 17.37 & 313.57 & & 2007 & 351 & 94.42 & 122.45 & 6.76 & 723.51 \\
\hline & 2008 & 22 & 144.08 & 124.66 & 56.52 & 590.95 & & 2008 & 251 & 241.03 & 302.06 & 22.33 & 2294.03 \\
\hline
\end{tabular}


Table 2

Summary Statistics

Germany

Variable

Obs

Mean

Std. Dev.

Min

Max

$25^{\text {th }} \%$ ile

$75 \mathrm{t}^{\mathrm{h}} \%$

Firm Characteristics

cds spread (bp)

leverage ratio

return

std dev

rating

totalassets

ROA

$\begin{array}{lr}110 & 65.70 \\ 110 & 0.18 \\ 110 & 0.0001659 \\ 110 & 0.0207309 \\ 109 & 16.21 \\ 110 & 201,305 \\ 110 & 0.0276195\end{array}$

$\begin{array}{rr}81.18 & 11.93 \\ 0.09 & 0.01 \\ 0.0014356 & -0.0039828 \\ 0.0192869 & 0.008469 \\ 2.64 & 7.00 \\ 367,056 & 8,070 \\ 0.0273433 & -0.0734472\end{array}$

1.93

828

7.00

$0.0273433-0.0734472$

CEO Compensation totalcompensation (thousands $€$ ) bonus (thousands $€$ ) salary (thousands $€$ ) bonus/total compensation equity/total compensation

$\begin{array}{lr}93 & 4,583 \\ 93 & 2,289 \\ 93 & 1,084 \\ 93 & 0.50 \\ 93 & 0.19\end{array}$

2,714

1,481

372

0.15

0.15
1,284

0

600

0.00

0.00

590.95
0.39
.0059378
.1563522
21.00
$2,193,953$
.1354305

0.39

378

1.00

0.1354305
20.82

0.11

$-0.000391$

0.0122371

15.00

24,804

0.0090073
0.0009
0.0195
1
164
0.0404

U.S.

\begin{tabular}{|c|c|c|c|c|c|c|c|}
\hline Variable & Obs & Mean & Std. Dev. & Min & Max & $25^{\text {th }} \%$ ile & $75 \mathrm{t}^{\mathrm{h}} \%$ \\
\hline cds spread (bp) & 1559 & 110.27 & 173.98 & 3.76 & 2294.03 & 29.20 & \\
\hline leverage ratio & 1559 & 0.26 & 0.16 & 0.00 & 1.00 & 0.14 & \\
\hline return & 1535 & 0.0002111 & 0.0013931 & -0.0109549 & 0.0107943 & -0.0003601 & 0.0010 \\
\hline std dev & 1535 & 0.0204201 & 0.013323 & 0.0068095 & 0.1371292 & 0.0126542 & 0.022 \\
\hline rating (S\&P) & 1507 & 14.49 & 2.82 & 6.00 & 22.00 & 13.00 & \\
\hline rating (Moody's) & 1360 & 14.25 & 2.98 & 3.00 & 22.00 & 13.00 & \\
\hline totalassets & 1559 & 32,731 & 85,754 & 545 & $1,120,645$ & 5,706 & \\
\hline ROA & 1559 & 0.0512051 & 0.0817489 & -0.8526002 & 0.9533648 & 0.0240289 & 0.088 \\
\hline \multicolumn{8}{|c|}{ CEO Compensation } \\
\hline totacompensation (thousands \$) & 1559 & 10,359 & 9,769 & 102 & 134,458 & 4,464 & \\
\hline bonus (thousands $\$$ ) & 1559 & 1,325 & 3,029 & 0 & 35,500 & 0 & \\
\hline salary (thousands \$) & 1559 & 1,061 & 427 & 0 & 5,613 & 850 & \\
\hline bonus/total compensation & 1559 & 0.13 & 0.18 & 0.00 & 1.00 & 0.00 & \\
\hline equity/total compensation & 1559 & 0.22 & 0.30 & 0.00 & 1.00 & 0.00 & \\
\hline
\end{tabular}




\section{Table 3 \\ U.S. panel}

Coefficients from pooled regressions of annual CDS spreads on firm characteristics and CEO compensation for 418 U.S. firms during the time period 2004-2008. The dependent variable is the logarithm of the average of firm's daily CDS spreads within each calendar year. Rating is Moody's rating (Aaa + rated bonds are assigned a value of 23 and D rated bonds are assigned a value of 1). Lratio is leverage ratio, defined as long term debt to total assets. Return is stock return (daily CRSP returns during the calendar year), Equity standard deviation (Stddev) is calculated each year at the firm level from daily CRSP returns during the calendar year). Return on Assets (ROA) is net income divided by total assets. The variable ltotalassets is the logarithm of total assets. The variable bonus/total compensation is bonus divided by total compensation (sum of salary, bonus, other annual, total value of restricted stock granted, total value of stock options granted, long term incenctive payouts (LTIP), and al other compensation). Equity/total compensation is the ratio of the sum of options, LTIP, and restricted shares) to total compensation.

\begin{tabular}{|c|c|c|c|c|c|c|}
\hline Variable & $\begin{array}{l}\text { Pooled OLS } \\
\text { (i) }\end{array}$ & $\begin{array}{l}\text { Pooled OLS } \\
\text { (ii) }\end{array}$ & $\begin{array}{l}\text { Pooled OLS } \\
\text { (iii) }\end{array}$ & $\begin{array}{l}\text { Pooled OLS } \\
\text { (iv) }\end{array}$ & $\begin{array}{l}\text { Pooled OLS } \\
\text { Fixed effects }^{1} \\
\text { (v) }\end{array}$ & $\begin{array}{l}\text { Pooled OLS } \\
\text { Fixed effects } \\
\text { (vi) }\end{array}$ \\
\hline rating & $\begin{array}{l}-0.193955^{\star \star \star} \\
(0.005911)\end{array}$ & $\begin{array}{l}-0.1950657^{* * *} \\
(0.0059291)\end{array}$ & $\begin{array}{l}-0.203463^{\star \star *} \\
(0.0061916)\end{array}$ & $\begin{array}{l}-0.205112^{\star \star *} \\
(0.0062065)\end{array}$ & $\begin{array}{l}-0.1434469^{\star \star \star} \\
(0.0125378)\end{array}$ & $\begin{array}{l}-0.1493335^{\star * *} \\
(0.0125593)\end{array}$ \\
\hline Iratio & $\begin{array}{l}0.6958926^{\star \star \star} \\
(0.1007775)\end{array}$ & $\begin{array}{l}0.7182224^{\star *} \\
(0.1012338)\end{array}$ & $\begin{array}{l}0.5799394^{\star \star \star} \\
(0.1045865)\end{array}$ & $\begin{array}{l}0.5988116^{\star \star *} \\
(0.1047083)\end{array}$ & $\begin{array}{l}0.6564136^{\star \star *} \\
(0.2016928)\end{array}$ & $\begin{array}{l}0.6300831^{\star \star *} \\
(0.2014109)\end{array}$ \\
\hline return & $\begin{array}{l}-83.201^{* \star \star} \\
(9.752067)\end{array}$ & $\begin{array}{l}-80.50633^{\star \star \star} \\
(9.719379)\end{array}$ & $\begin{array}{l}-52.43458^{\star \star *} \\
(9.424493)\end{array}$ & $\begin{array}{l}-50.51777^{\star \star \star} \\
(9.369844)\end{array}$ & $\begin{array}{l}-34.11562^{\star \star *} \\
(9.812334)\end{array}$ & $\begin{array}{l}-31.52461^{\star \star *} \\
(9.730601)\end{array}$ \\
\hline stddev & $\begin{array}{l}30.74359^{\star \star \star} \\
(0.9922983)\end{array}$ & $\begin{array}{l}30.91256^{\star \star \star} \\
(1.006582)\end{array}$ & $\begin{array}{l}18.02816^{\star \star \star} \\
(1.333216)\end{array}$ & $\begin{array}{l}18.20635^{\star \star \star} \\
(1.334342)\end{array}$ & $\begin{array}{l}16.80602^{\star \star \star} \\
(1.454434)\end{array}$ & $\begin{array}{l}16.87376^{\star \star \star} \\
(1.453474)\end{array}$ \\
\hline ROA & $\begin{array}{l}-0.652061^{\star * *} \\
(0.1731767)\end{array}$ & $\begin{array}{l}-0.6042488^{\star \star \star} \\
(0.1740969)\end{array}$ & $\begin{array}{l}-0.8189819^{\star \star \star} \\
(0.1651544)\end{array}$ & $\begin{array}{l}-0.7402527^{\star \star \star} \\
(0.1654211)\end{array}$ & $\begin{array}{l}-0.8691521^{\star \star *} \\
(0.1849505)\end{array}$ & $\begin{array}{l}-0.7802886^{\star \star \star} \\
(0.1844573)\end{array}$ \\
\hline Itotalassets & $\begin{array}{l}-0.0158057 \\
(0.0140243)\end{array}$ & $\begin{array}{l}-0.0138903 \\
(0.0140738)\end{array}$ & $\begin{array}{l}-0.0337858^{\star \star} \\
(0.0150833)\end{array}$ & $\begin{array}{l}-0.0317206^{\star *} \\
(0.0151065)\end{array}$ & $\begin{array}{l}0.0518045 \\
(0.0534712)\end{array}$ & $\begin{array}{l}0.0853787 \\
(0.0547047)\end{array}$ \\
\hline $\begin{array}{l}\text { Bonus/total } \\
\text { compensation }\end{array}$ & $\begin{array}{l}0.2746732^{\star \star \star} \\
(0.0656094)\end{array}$ & & $\begin{array}{l}0.3191961^{\star * *} \\
(0.0616692)\end{array}$ & & $\begin{array}{l}0.3496483^{\star * *} \\
(00665464)\end{array}$ & \\
\hline $\begin{array}{l}\text { Equity/total } \\
\text { compensation }\end{array}$ & & $\begin{array}{l}0.1211229 \star \star \star \\
(0.0367038)\end{array}$ & & $\begin{array}{l}0.1774378^{\star \star \star} \\
(0.0341256)\end{array}$ & & $\begin{array}{l}0.1939177^{\star \star \star} \\
(0.0355689)\end{array}$ \\
\hline Year dummy & no & no & yes & yes & yes & yes \\
\hline Ind dummies & no & no & yes & yes & yes & yes \\
\hline Observations & 1343 & 1343 & 1343 & 1343 & 1343 & 1343 \\
\hline $\mathrm{R}^{2}$ & 0.8317 & 0.8305 & 0.8469 & 0.8465 & 0.8028 & 0.7905 \\
\hline
\end{tabular}

Notes: $* * *, * *, *$ denote significance at the levels of $1 \%, 5 \%$ and $10 \%$, respectively; standard errors in parentheses.

${ }^{1}$ Panel regressions (OLS) with firm fixed effects.

All regressions include an intercept (not reported). Regressions iii, iv, v and vi include a "crisis" year dummy for 2008

and industry fixed effects (not reported); industry fixed effects are based on four digit-SIC codes following Fama and French (1997). 


\section{Table 4}

\section{German panel}

Coefficients from pooled regressions of annual CDS spreads on firm characteristics and CEO compensation for 22 German firms during the time period 2004-2008. The dependent variable is the logarithm of the average of firm's daily CDS spreads within each calendar year. Rating is Moody's rating (Aaa+ rated bonds are assigned a value of 23 and D rated bonds are assigned a value of 1; if Moody's rating is missing, we replaced it with S\&P credit rating in order to keep the sample). Lratio is leverage ratio, defined as long term debt to total assets. Return is stock return (daily returns during the calendar year), Equity standard deviation (Stddev) is calculated each year at the firm level from daily returns during the calendar year). Return on Assets (ROA) is net income divided by total assets. The variable ltotalassets is the logarithm of total assets. The variable bonus/total compensation is bonus divided by total compensation (sum of salary, bonus, other annual, total value of restricted stock granted, total value of stock options granted, long term incenctive payouts (LTIP), and al other compensation).

Equity/total compensation is the ratio of the sum of options, LTIP, and restricted shares) to total compensation.

\begin{tabular}{|c|c|c|c|c|c|c|}
\hline Variable & $\begin{array}{l}\text { Pooled OLS } \\
\text { (i) }\end{array}$ & $\begin{array}{l}\text { Pooled OLS } \\
\text { (ii) }\end{array}$ & $\begin{array}{l}\text { Pooled OLS } \\
\text { (iii) }\end{array}$ & $\begin{array}{l}\text { Pooled OLS } \\
\text { (iv) }\end{array}$ & $\begin{array}{l}\text { Pooled OLS } \\
\text { Fixed effects } \\
\text { (v) }\end{array}$ & $\begin{array}{l}\text { Pooled OLS } \\
\text { Fixed effects }^{1} \\
\text { (vi) }\end{array}$ \\
\hline \multirow[t]{2}{*}{ rating } & $-0.1662189 * * \star$ & $-0.16451985^{\star \star \star}$ & $-0.1498754^{\star \star \star}$ & $-0.1552611^{\star \star \star}$ & -0.0453854 & -0.0444814 \\
\hline & (0.0298786) & (0.0299917) & (0.0311519) & $(0.0315966)$ & (0.0401153) & (0.0423283) \\
\hline \multirow[t]{2}{*}{ Iratio } & -0.5903735 & -0.6132612 & 0.6088122 & 0.4037348 & $1.886221^{\star \star \star}$ & $1.526739 *$ \\
\hline & $(0.5738575)$ & $(0.5733121)$ & (0.6114223) & (0.6116323) & (0.8255194) & (0.8476843) \\
\hline return & (28.35873) & (27.26165) & (39.38243) & (38.97181) & (39.55531) & (39.42715) \\
\hline \multirow[t]{2}{*}{ stddev } & $16.74132^{\star \star \star}$ & $17.56942^{\star \star \star}$ & 6.067222 & $8.123986^{\star \star}$ & 1.045691 & 3.498968 \\
\hline & $(2.241449)$ & (2.222308) & (3.797095) & (3.75218) & (3.672468) & (3.65428) \\
\hline \multirow[t]{2}{*}{ ROA } & -3.286603 & -3.501044 & -2.104432 & -2.758738 & -0.7628094 & -1.692806 \\
\hline & (2.322351) & $(2.280076)$ & (1.959964) & $(0.974578)$ & (1.957227) & (1.982966) \\
\hline compensation & (0.3128361) & & (0.2732025) & & (0.2940499) & \\
\hline \multirow{3}{*}{$\begin{array}{l}\text { Equity/total } \\
\text { compensation }\end{array}$} & & & & & & \\
\hline & & -0.2243645 & & 0.045272 & & 0.023305 \\
\hline & & $(0.2947523)$ & & $(0.2546585)$ & & (0.2743833) \\
\hline Year dummy & no & no & yes & yes & yes & yes \\
\hline Ind dummies & no & no & yes & yes & yes & yes \\
\hline Observations & 92 & 92 & 92 & 92 & 92 & 92 \\
\hline $\mathrm{R}^{2}$ & 0.8063 & 0.8087 & 0.9034 & 0.9034 & 0.7333 & 0.6922 \\
\hline
\end{tabular}

